\title{
Lithuanian forest biomass resources: legal, economic and ecological aspects of their use and potential
}

Iveta Varnagirytė-Kabašinskiené ${ }^{*}$ D, Diana Lukminè, Stasys Mizaras, Lina Beniušienè and Kęstutis Armolaitis

\begin{abstract}
The development of bioenergy markets is beneficial from a climate perspective and helps ensure sustainable forest management both locally and globally. This study aimed to provide an overview of the current state of Lithuanian forest biomass resources with a particular focus on the legal, economic and ecological aspects of forest biomass use for energy and to identify the lessons that should be learned from the history of biomass introduction in the country's energy sector. These experiences and lessons are valuable both nationally and internationally, where good practices and challenges for the introduction and development of forest biomass for energy production are revealed. We examined the question of whether regulatory drivers in the energy sector can increase forest biomass use for energy production and contribute to sustainable development of Lithuania. To answer this question, we described the legal and market instruments regulating forest biomass use for energy production, the forestry sector and renewable energy policy in Lithuania, the current and potential amount of forest biomass available for energy production and ecological considerations relating to forest biomass use for energy. In Lithuania, forest biomass resources are strategically important for the renewable energy sector. The National Energy Strategy of Lithuania aims to increase the share of renewable energy sources, including forest biomass, within the total energy consumption, with targets of 30\% in 2020, 45\% in 2030 and $80 \%$ in 2050. Lithuania successfully achieved the target of EU legislation on renewables in 2015 ahead of the obligation to achieve it in 2020. Renewable energy is mainly used in heating, as well as in the electricity and transport sectors. This has resulted in a significant price reduction for end users due to the increased use of biomass, mainly local forest biomass, for heat energy production and in the emergence of a biofuel exchange, which acts as a system of biomass auctions that to some extent prevent unjustified price increases. Legislation developed for the energy biomass market in Lithuania allows efficient restructuring of the energy sector, especially for heat production. The Lithuanian energy sector has already successfully replaced imported and relatively expensive natural gas with locally available cheaper renewable energy sources (RES). Compliance with formal environmental regulations is required to protect the soil, ground vegetation, understory and biodiversity during commercial tree harvesting. Lithuania has basic guidelines for the use of wood ash as a compensatory fertiliser, with strict requirements for the chemical quality of wood ash.
\end{abstract}

Keywords: Renewable energy sector, Forest biomass for energy, Legislation, Market instruments, Environmental impact

\footnotetext{
* Correspondence: iveta.kabasinskiene@lammc.lt

Institute of Forestry, Lithuanian Research Centre for Agriculture and Forestry

(LAMMC), Liepu str. 1, Girionys, LT-53101 Kaunas district, Lithuania
}

(c) The Author(s). 2019 Open Access This article is distributed under the terms of the Creative Commons Attribution 4.0 International License (http://creativecommons.org/licenses/by/4.0/), which permits unrestricted use, distribution, and reproduction in any medium, provided you give appropriate credit to the original author(s) and the source, provide a link to the Creative Commons license, and indicate if changes were made. 


\section{Background}

Renewable energy sources (RES) are recognised widely as an important means for the energy sector to achieve the environmental, economic and social aims of sustainable development [1-4]. The bioenergy market specifically can help foster sustainable forest management at the regional, national and international levels. The production of biomass for energy from forest and agricultural waste is becoming an increasingly important sector of the economy, with growing volumes produced, numbers of jobs and added value.

As the world moves towards the goal of $100 \%$ renewable energy by 2050 in order to achieve the goal agreed at COP21 in Paris in 2015, individual countries seek to develop strategies for the accelerated development of renewable energies $[5,6]$. Lithuania, together with other European Union (EU) Member States, has committed to ending fossil fuel use to stop further increases in greenhouse gas (GHG) concentration in the atmosphere [7-9]. Since growing trees absorb a significant amount of the carbon released in the process of biomass combustion, the GHG emissions produced by burning fossil fuels can be reduced by substituting these with renewable forest biomass. However, while biomass combustion is beneficial from a climate perspective, it can have local and global impacts on other aspects of environmental quality [10-12].

The EU Member States plan to achieve a 32\% share of renewable energy in their total energy consumption by 2030 [13]. The use of biomass for district heating in the Baltic countries-Lithuania, Latvia and Estonia-which has increased significantly in recent years, contributes towards this goal. In 2015, the main energy sources for the Baltic countries were petroleum products $(48 \%)$, biomass and waste $(22 \%)$, and natural gas (21\%) [14]. In Lithuania, the amount of biomass used for district heating and electricity has increased since about 2007, and the country continues to increase the share of biomass in energy production. By 2020 , the share of centrally supplied heat energy produced from RES is planned to increase to $60 \%$, and the share of renewable energy in final energy consumption should increase to $23 \%$ [13, 15]. Despite its already leading position in renewable energy, Lithuania plans to further develop that sector in order to mitigate climate change and increase the country's competitiveness [15]. It is planned that by 2030 installed power capacity from RES will be 2.5 times higher than in 2017, and almost half of the energy consumed will be produced from RES. By 2050, most of the energy used in the heating, electricity and transport sectors will come from RES [15].

Decisions in the Lithuanian energy sector are being made with little regard for the economic, social and environmental aims of sustainable development [16]. So far, there has been no comprehensive review of the Lithuanian use of forest biomass for energy. The objective of this paper is to explore how decisions in the energy sector can improve its contribution to overall sustainable development in Lithuania. We address this objective by providing an interdisciplinary overview of forest biomass resources in Lithuania and a synthesis of the legal, economic and ecological aspects of the use of those resources for renewable energy production. The specific research questions include the following:

- What are the key political and market-based instruments acting for implementation of renewables for energy in Lithuania?

- What is the current supply of renewables for energy in Lithuania?

- What changes and challenges have taken place in the forestry and renewable energy sectors in Lithuania during last decade?

- What forest biomass resources are available for energy in Lithuania?

- What are the environmental sustainability implications of using forest biomass for energy in Lithuania, and how are possible risks being mitigated through regulation?

- What are the future perspectives and challenges for forest biomass use for energy in Lithuania?

\section{Data and materials}

This section describes the research methods that were followed to assess different national and EU legislation, statistical databases and other related documents implemented to incentivise forest biomass use for energy.

The Lithuanian case study includes descriptive approaches, as well as qualitative analysis. The review of regulatory drivers covers legal regulations of forest biomass use in energy production and also marketbased instruments. We first analysed EU legislation, continuing with the analysis of Lithuanian legal issues, including national programmes, strategies and laws (Table 1; Appendix 1). The review of current energy use and supply provided by renewables is based on analysis of statistical data on renewables supply, share of different fuel types and the price of heat supplied to central district heating. The review of current information on the forest sector is based on analysis of literature and statistical data on historical changes and the current situation in Lithuanian forests, including tree species composition and ownership. The description of biomass supply from the forestry sector is based on data of current and potential amounts of forest biomass from different sources (harvest residues, short rotation plantations) 
Table 1 Reviewed EU and Lithuanian legislation in energy and forestry sectors

Energy sector

Renewable Energy Directive (2009/28/EC) [19]

Renewable Energy Directive (2018/2001/EU) [20]

European Commission (EC) document on Sustainability of Bioenergy [21]

EC document on Sustainability of Solid and Gaseous biomass [22] National Energy Independence Strategy of the Republic of Lithuania [13] National Strategy for the Development of Renewable Energy Sources [23]

Law on Energy of the Republic of Lithuania [24]

Law on Energy from Renewable Sources of the Republic of Lithuania

[25]

Law on the Heat Sector of the Republic of Lithuania [26]

Forestry sector

National Forestry Sector Development Programme 2012-2020 [27]

Rural Development Programme 2014-2020 [28]

Law on Forests of the Republic of Lithuania [29]

National Forestry Accounting Plan by Lithuania [30]

Strategy of State Forest Enterprise Activity 2019-2023 [31]

Regulations on Wood Ash Disposal and Use [32]

Regulations for Forest Fellings [33]

(Table 1). The last chapter, analysis of ecological risks and their regulation is based only on Lithuanian regulations and scientific findings of local studies. Though other countries face similar challenges $[17,18]$, this case study only deals with environmental issues covered by Lithuanian legislation and other documents with related information on forest biomass use for energy.

'Forest biomass' is taken here to include firewood and wood chips from aboveground logging residues (low-quality stems, tops, branches, needles and leaves) from pre-commercial and commercial harvesting, as well as woody material from short rotation plantations (basically willows). In addition to the above, by-products such as sawdust, waste from the agriculture sector and wood processing industries are included in the broader term 'biomass'. When citing text from the reviewed sources, the translations used are mainly unofficial versions by the authors, since official translations are rare.

\section{Energy policy and the goal for renewables in Lithuania}

This case study is specific to Lithuania but, as a member of the European Union (EU), Lithuania is subject to the obligations and privileges of such membership as defined within EU legislation common to all members. The Renewable Energy Directive (2009/ 28/EC) of the European Parliament established an overall policy for the production and promotion of energy from RES in the EU [19]. It requires the EU to fulfil at least $20 \%$ of its total energy needs with renewables by 2020 . This target is to be achieved through the attainment of individual national targets. The directive stipulates that all EU countries must also ensure that at least $10 \%$ of their transport fuels come from RES by 2020. Lithuania's national renewable energy target is 23\%. In 2015, Lithuania had already achieved a share of $25.8 \%$ of renewable energy in its gross final energy consumption [9]. Reaching national renewable energy target for 2020 by 2015 did not slow down ambitions for the use of renewables and Lithuania aims to further develop renewable energy in its economy.

Moving forward, the revision of the Directive 2009/28/EC was initiated to reflect global change since 2009, increase climate change ambitions and leverage international investment in renewable technologies. Furthermore, the revised Renewable Energy Directive (2018/2001/EU) of the European Parliament aimed at keeping the $\mathrm{EU}$ as a global leader in renewables and helping it meet its GHG emissions reduction commitments under the 2015 Paris Agreement on Climate Change [20]. In this directive, a new binding renewable energy target for the EU for 2030 of at least $32 \%$ was established, with a clause for a possible upwards revision by 2023. EU countries are required to draft 10-year National Energy and Climate Plans for 2021-2030, outlining how they will meet the new 2030 targets for renewable energy and for energy efficiency. Member States need to submit a draft National Energy and Climate Plan by 31 December 2018 and are to be ready to submit final plans to the EC by 31 December 2019 . Most of the other new elements in the revised directive need to be transposed into national law by Lithuania, as a Member State, by 30 June 2021. According to the Directive 2018/2001/EU, the overall objective for renewables in Lithuania is $45 \%$ in 2030 , defined as $45 \%$ for the renewables share in final energy consumption, $90 \%$ in the central heating sector, $15 \%$ in the transport sector, $45 \%$ in final electricity consumption and $70 \%$ for the renewables share in electricity generation [34]. The Lithuanian government is considering a new support scheme for producers of renewables. EU legislation provides renewable energy targets for Member States as goals to plan national issues for energy sector improvements and climate change mitigation. The increased use of sustainable renewables across the EU would contribute to some extent to the creation of the Energy Union [34].

Lithuanian legislation provides for taking active steps to fulfil the established EU targets, reinforcing these ambitions with local commitments and goals. In Lithuania, several pieces of legislation have been put into force to elaborate the energy sector policy 
and promote the use of RES (Appendix 1). The main policy documents for energy sector development are the National Energy Independence Strategy and the Strategy Action Plan [13]. One of the aims of the strategies is to ensure Lithuania's energy independence by the year 2020 by strengthening national energy security and competitiveness. The Law on Energy [24] and the Law on the Heat Sector [26] establish the legal basis for state management, regulation, supervision and control of the energy sector, including the general criteria, conditions and requirements for public relations. They also define the main objectives of government energy policy and regulate government management of the heat sector, including the activities of the heat sector entities, their interrelationships and responsibilities, and their relations with heat consumers. Our overall assessment of these instruments showed that they are to (a) ensure the country's energy independence by strengthening a secure and reliable energy supply, (b) contribute to reduction of environmental pollution, (c) promote the use of domestic RES and (d) ensure reliable and high quality heat supply to consumers at minimum cost.

The main legislation promoting increased use of RES, including biomass, in heat production are the National Strategy for the Development of Renewable Energy Sources and its Action Plan [23], the Law on Energy from Renewable Sources of the Republic of Lithuania [25], and the National Forestry Sector Development Programme 2012-2020 [27]. The National Strategy for the Development of Renewable Energy Sources [23] is intended to ensure an increased share of RES in the country's energy balance, in order to meet energy needs in the electricity, heating and transportation sectors using domestic resources as much as possible, and phasing out imported polluting fossil fuels. This would enhance energy security and energy independence and contribute towards international efforts to reduce GHG emissions. The Law on Energy from Renewable Sources of the Republic of Lithuania [25] establishes the legal basis for state administration, regulation, supervision and control of the renewable energy sector and for organising activities in the renewable energy sector. It mandates the state regulation and supervision of the activities of energy grid operators and producers of energy from RES, including their relations with controlling authorities. The law should also help ensure increased use of RES in the energy sector.

The National Forestry Sector Development Programme 2012-2020 [27] is intended to retain the balanced volume between annual increment of timber and all forest fellings, including pre-commercial thinnings, sanitary (to improve health of the forest and eliminate stem pests and spread of dangerous infections by removing damaged, dying, windfall trees) and final fellings. Also, it is intended to increase the volume of non-merchantable timber and logging residues used for energy production. For the latter, it sets a target of $0.5 \mathrm{~mm}^{3}$ in 2020. Financial instruments (listed in Appendix 1) are also in place to promote the development and use of RES, including biomass.

The BALTPOOL Biomass Exchange (hereafter, BALTPOOL) is a market-based instrument promoting the use of biomass in heat production [35]. On 27 September 2012, the National Control Commission for Prices and Energy issued an operating licence to BALTPOOL, a Baltic region energy resources exchange, entitling it to organise trade of solid biomass for energy. BALTPOOL was thus enabled to act as an intermediary for companies producing, supplying and buying biomass for energy in Lithuania. The licence entered into force on 31 July 2013 as one of the instruments for fair competition in the energy sector. Since 2016, all biomass for energy production has been purchased on BALTPOOL, which is legally regulated, but with rules that allow purchase of biomass outside the exchange if the price paid is lower than it would be on the exchange. Heat and electricity producers and suppliers of biomass are invited to trade on BALTPOOL and currently 251 companies producing and supplying energy biomass and more than 100 buyers are registered. Wood chips, one of the most popular types of biomass, are traded on the biomass exchange. During the 2017-2018 heating season, biomass was supplied through BALTPOOL under 4067 contracts. The total amount of biomass sold during that heating season was 12.41 PJ, of which $96.5 \%$ was purchased by 102 buyers from Lithuania and Latvia, including both central heat supply enterprises and regulated independent heat supply enterprises [35]. More than $90 \%$ of all suppliers in BALTPOOL are Lithuanian.

The Lithuanian woody biomass market is strongly influenced by wood chips supplied from Belarus at prices cheaper than for locally supplied chips [36]. In 2017, $0.64 \mathrm{~mm}^{3}$ of wood chips were imported from Belarus, $25 \%$ of all wood chips sold on BALTPOOL. In 2018, imports increased to about $1 / 3$ of the total biomass market. The largest sellers on BALTPOOL are thus not local chip producers but wholesalers of Belarusian wood chips.

Competition among heat producers is organised through monthly heat sale auctions, on the national fuel and energy exchange in Lithuania, BALTPOOL, on which all heat producers are required to buy fuel and sell heat in individual municipalities. The 
experience of the exchange attracts interest from foreign politicians and officials. BALTPOOL is extending its activities to other countries.

In summary, both EU and Lithuanian legislations devote special attention to the expanded use of renewables at the EU and national levels, focusing on forest biomass. The Renewable Directive (2009/28/EC) sets mandatory national targets for the share of renewable energy for each EU country, to be reached in 2020. The national targets are set with a view to achieving the EU 20\% renewable energy target by 2020. Lithuania's national renewable energy target was $23 \%$, which was achieved in 2015 , with a share of $25.75 \%$ of renewable energy in gross final energy consumption. The market-based instrument BALTPOOL had strong impact on promoting the development of biomass use in heat production.

\section{Current energy use and supply provided by renewables}

Lithuania has an annual domestic heating season (when the outside temperature is lower than + $10^{\circ} \mathrm{C}$ ) of about $6-7$ months [37]. According to the National Renewable Energy Action Plan [23], the possibilities for wider use of locally available fossil resources (peat, oil) are limited. It is therefore very important to increase the use of energy from RES. National energy sources in 2016 included crude oil and petroleum products $(38.9 \%)$, natural gas $(25.1 \%)$, RES (20.0\%), electricity (9.7\%) and coal, peat and others $(6.3 \%)$ [38]. The RES presently in use include solid biomass $(83.0 \%)$, wind $(6.7 \%)$, liquid biofuels (3.9\%), hydro-electricity (2.7\%) and others (biogas, municipal waste, solar, geothermal) $(3.7 \%)$. In the district heating sector, biomass and municipal waste are most important, but the share of natural gas is still relatively high (Fig. 1). However, Lithuania has made progress compared to the $\mathrm{EU}$ as a whole in which use of fossil fuels for heat production is still very high at $70 \%$ [39]. Total annual energy consumption in Lithuania is about $180 \mathrm{PJ}$, made up of $36 \mathrm{PJ}$ in final electricity consumption, 72 PJ in heating, and $72 \mathrm{PJ}$ in liquid transportation fuels [38].

Natural gas from Russia was the dominant fuel used in district heating until 2013 (Fig. 2). Since then, Lithuania has been one of the post-communist countries experiencing a rapid increase in use of wood-based energy sources, and heating plants using fossil fuels were modified to use biomass. About $65 \%$ of heat consumed in district heating is produced in these centralised systems. However, inefficient use of heat energy is still considered one of the biggest problems in the Lithuanian heating sector. The average annual heat consumption in Lithuanian buildings is $0.75 \mathrm{GJ} \mathrm{m} \mathrm{m}^{-2}$, while the corresponding figure for neighbouring Nordic countries is about $0.46 \mathrm{GJ} \mathrm{\textrm {m } ^ { - 2 }}$ [16]. Reducing inefficiencies would save a significant amount in heating costs and reduce GHG emissions.

Increasing energy production from renewables can diversify energy sources for heat production and reduce the negative environmental impact of the district heating sector. Over the last decade, the proportion of forest biomass used in final primary energy consumption has increased rapidly since about 2010 and further expansion is expected (Fig. 2). Heating plants currently consume about $22 \mathrm{PJ}$ of forest biomass annually (see Fig. 1).

Forest biomass has been recognised as a strategically important renewable resource for the energy sector in Lithuania. RES usually face market barriers such as high initial investment cost and low competitiveness of new technologies compared to old

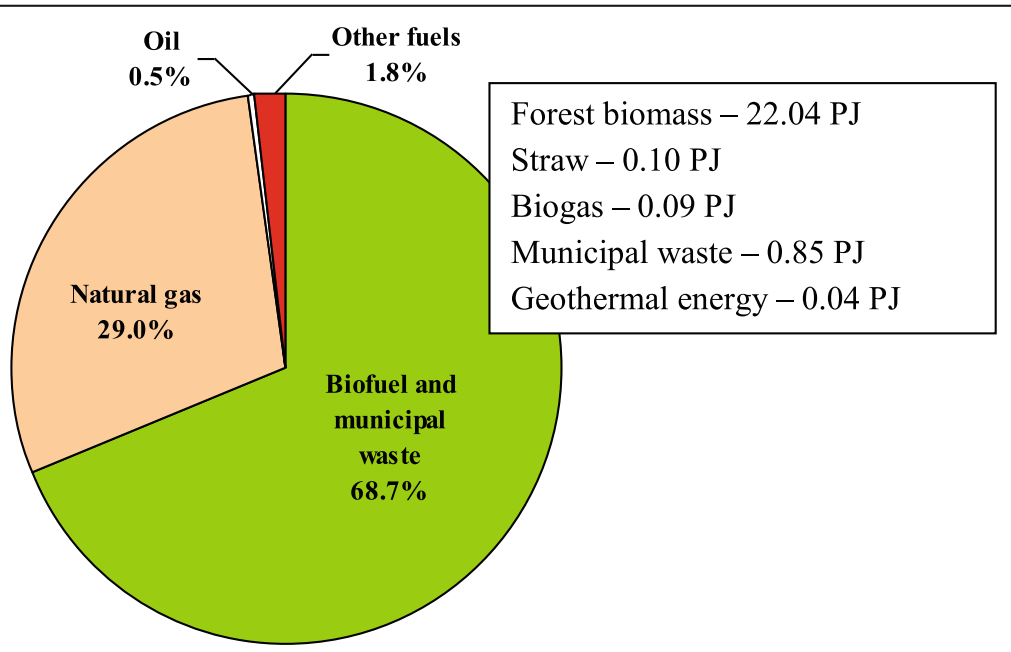

Fig. 1 Share of different fuel types in the district heating sector in Lithuania, 2017. Data source: Lithuania District Heating Association [40] 


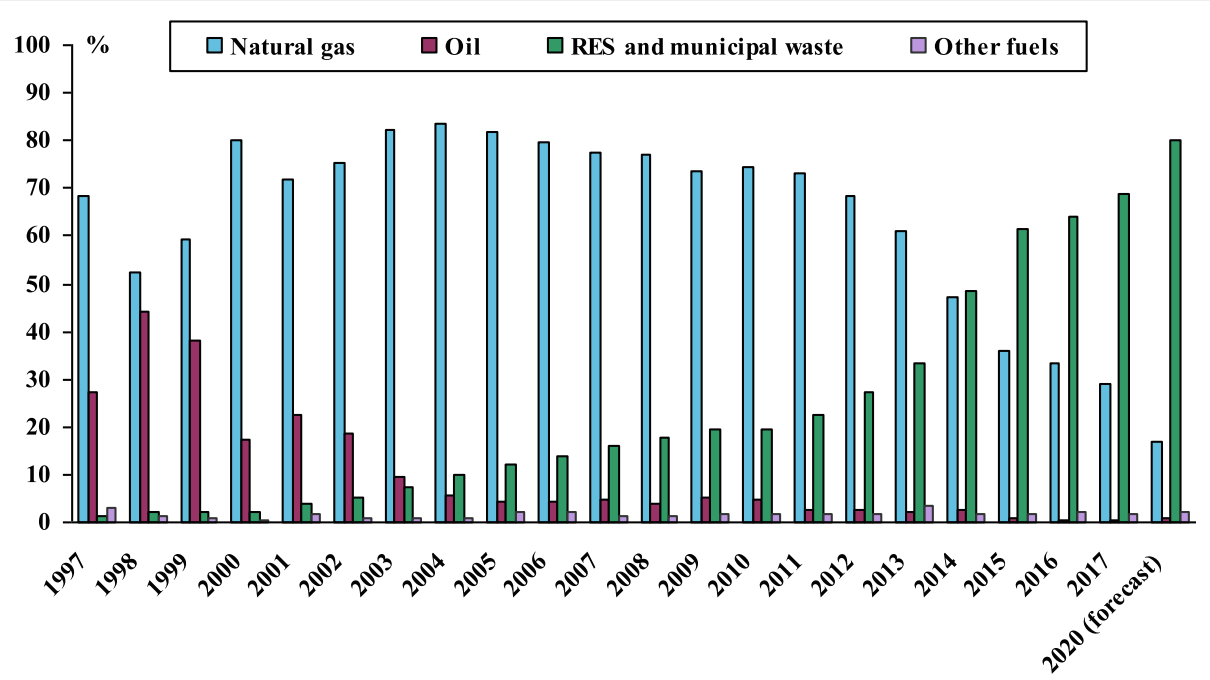

Fig. 2 Proportion of different fuel types used in the district heating sector in Lithuania, 1997-2017, with a forecast for 2020. Data source: Lithuania District Heating Association [40]

ones. The State promotes economically viable investments in heat production from biomass, giving priority to combined heat and power plants. The use of biomass fuel in power plants specifically designed for biomass is much cheaper and more environmentally friendly than the use of old technologies [16]. In the long term, locally available RES could give economic and ecological benefits. On the other hand, the use of forest biomass in the district heating sector does not cover the country well, with about $70 \%$ of individual houses still using firewood for heating. However, these houses are not included in the district heating grid.
It is expected that investment in heat production from biomass will not increase the heat price, and it has already made it possible to exceed the 2020 goal of $23 \%$ renewable energy in the final energy consumption.

During the period 1996-2017, the average price of heat supplied to central district heating systems in Lithuania fluctuated unevenly: the price remained relatively stable while it was fixed by regulation between 1996 and 2006, increased from 2007 to 2012 when price formation was left to the market and depended mostly on the increased cost of imported natural gas, and then decreased thereafter up to 2017 (Fig. 3) [40]. This decrease from 2012 to 2017 was

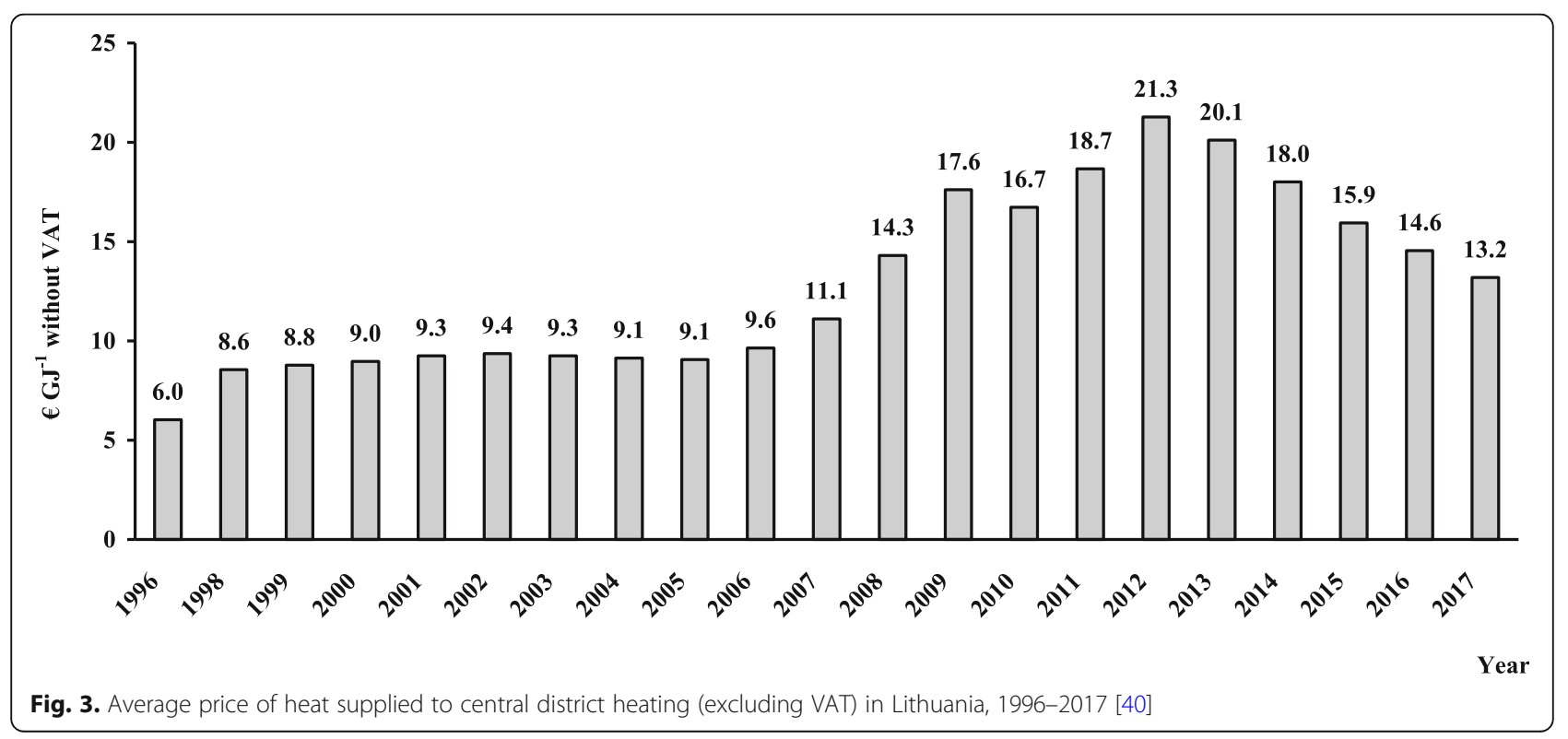


almost 38\%. Several factors may have influenced the reduction in central heat prices: first, the increased use of forest biomass for heat energy production; second, the use of local forest fuel resources; and, third, the emergence of the biofuel exchange, as explained in the previous section.

At the beginning of 2019, there were 52 licenced heat suppliers [41]. These companies produce and supply about $98 \%$ of the heat delivered through heating networks in 60 municipalities throughout the country [40]. The market share of biomass is currently 58.7\% [41]. Householders consume $73 \%$ of the heat produced, State institutions $13.2 \%$, and industry and other users only $13.8 \%$ [40].

Between 2000 and 2016, the use of combined biomass fuels in the district heating sector increased from 2 to 65\%, and the share of biomass in district heating exceeded the share of imported natural gas [40]. Biomass was used in public central heating power plants $(23.68 \%)$, public heating plants $(72.08 \%)$, internally by industry in heating plants $(4.06 \%)$, transformation by charcoal plants $(0.17 \%)$ and in the energy sector $(0.01 \%)$ [42].

In summary, solid biomass has the leading share among renewables, more than $80 \%$, in Lithuania. The proportion of forest biomass used in final primary energy consumption has increased rapidly since about 2010. Though renewables for energy production sometimes face market barriers such as high initial investment cost and low competitiveness, in the long term, its usage should give economic and ecological benefits. The peak in prices for natural gas in 2007-2012 and the EU's policy of greater use of renewables have led to the rapid construction of biomass-fired boilers and cogeneration plants in Lithuania. The result of state aid and incentive regulation was that already in 2017 about $70 \%$ of the total district heat production was from renewables.

\section{Current situation of the forestry sector in Lithuania}

Lithuania is situated on the eastern coast of the Baltic Sea between $53^{\circ} 54^{\prime}$ and $56^{\circ} 27^{\prime} \mathrm{N}$ latitude and between $20^{\circ} 56^{\prime}$ and $26^{\circ} 51^{\prime}$ E longitude. It has a total land area of $65,300 \mathrm{~km}^{2}$ (6.53 m ha). Of that area, $50 \%$ is lowland (up to $100 \mathrm{~m}$ above sea level), $29 \%$ is upland (150-200 $\mathrm{m}$ above sea level) and $21 \%$ consists of hilly areas (200-300 $\mathrm{m}$ above sea level) [43]. Lithuania is in the cool temperate moist IPCC climate region [44]. Agricultural land covers more than 50\% of the country and forest land amounts to about 33\% of total land area (2.2 $\mathrm{m} \mathrm{ha}$ ) $[45,46]$ (Table 2).

Lithuania falls in the transitional hemi-boreal forest zone of Europe with mixed deciduous and coniferous stands being most common. The major forest soil groups are Arenosols (32\%), Luvisols and Retisols (29\%) and Histosols (11\%) [47]. Forestry plays an important role in the Lithuanian economy and environment. During the period 2003-2017, the total growing stock volume increased by $90 \mathrm{~mm}^{3}$ and gross annual increment by $3.8 \mathrm{~mm}^{3}$.

Coniferous stands prevail in Lithuania, occupying 1.144 Mha, $55.6 \%$ of the forest area (Fig. 4). Scots pine (Pinus sylvestris L.) occupies the greatest area, 0.711 Mha, followed by Norway spruce (Picea abies (L.) Karst.) with 0.429 Mha. The total area of deciduous softwood and hardwood is 0.913 Mha (44.4\% of the forest area). Silver birch (Betula pendula Roth) and downy birch (Betula pubescens Ehrh.) stands predominate among deciduous stands, with 0.453 Mha. Other deciduous species, including European aspen (Populus tremula L.), black alder (Alnus glutinosa (L.) Gaertn.), grey alder (Alnus incana (L.) Moench), common oak (Quercus robur L.) and European ash (Fraxinus excelsior L.), occupy much smaller areas.

About half of all forest land in Lithuania (1.088 Mha, 49.7\%) is of state-owned [46] and all state forests are

Table 2 General characteristics of Lithuanian forests [46]

\begin{tabular}{lll}
\hline Characteristics & $01-01-2003$ & $01-01-2017$ \\
\hline Forest land area according to forest assessment, $\mathrm{m}$ ha & 2.045 & 2.190 \\
Total growing stock volume, $\mathrm{mm}^{3}$ & 453.4 & 542.7 \\
Mean growing stock volume, $\mathrm{m}^{3} \mathrm{ha}^{-1}$ & 226 & 256 \\
Total growing stock volume of mature stands, $\mathrm{mm}^{3}$ & 109.9 & 151.4 \\
Gross annual increment, $\mathrm{mm}^{3}$ & 16.0 & 19.8 \\
Gross annual increment, $\mathrm{m}^{3} \mathrm{ha}^{-1}$ & 8.0 & 8.5 \\
Volume change, $\mathrm{m}^{3} \mathrm{ha}^{-1}$ & Data not available & 3.0 \\
Forest coverage, \% & 31.3 & 33.5 \\
Forest area per capita, ha & 0.59 & 0.77 \\
Growing stock volume per capita, $\mathrm{m}^{3}$ & 131 & 191 \\
\hline
\end{tabular}




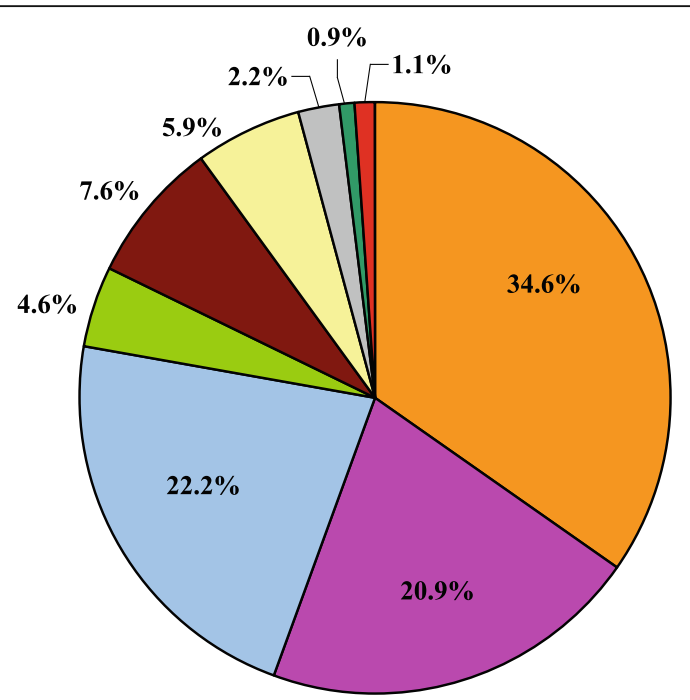

\begin{tabular}{|l|}
$\square$ Scots pine \\
$\square$ Norway spruce \\
$\square$ Silver and downy birch \\
$\square$ European aspen \\
$\square$ Black alder \\
$\square$ Grey alder \\
$\square$ Common oak \\
$\square$ European ash \\
$\square$ Other
\end{tabular}

Fig. 4 Proportions of the forest area of Lithuania occupied by different dominant tree species [46]

FSC-certified. PEFC sustainable forest management certification is not available in Lithuania because national standards are not yet developed. Other forests are under private ownership (0.883 Mha, $40.3 \%$ ) or stateowned forests that are reserved for property restitution (10\%). Since 1990, after Lithuania regained independence, forest ownership has changed greatly; however, the restitution of land to former owners has not been completed. In terms of function, Lithuanian stateowned and private forests are categorised as either (I) forest reserves (1.1\%), (II) special-purpose forests (ecosystem protection and recreational forests) (12.0\%), (III) protective forests $(14.6 \%)$ or (IV) commercial forests where timber production is prioritised (72.3\%). No forest management activity is allowed in I, while in II and III, forest management is strictly controlled by the Law on Forests (2001), which sets limits for stand harvesting age, size of clear cuts, etc.

During the Soviet period, all forest land was stateowned and forest management was centrally planned, as was the entire Lithuanian economy. After the restoration of independence in 1990, major political and socioeconomic changes occurred in the forest sector [48], including the emergence of private forest ownership, a free market for wood, adoption of foreign technologies, EU support, and the expanded focus on social and environmental forest functions. When independence was restored, forest property rights were also restored, and the structure of forest ownership changed due to an ongoing land reform process which is still ongoing. All forest land was transferred to a national network of 42 state forest enterprises under the Ministry of Forestry, whose main responsibilities included forest management, preservation of forest genetic resources, afforestation, forest protection (fire, insects and diseases) and allocation of forest areas for scientific purposes or to meet public needs.

In 2018, the 42 state forest enterprises, along with the State Forest Management Institute, were merged into a single company, the VI Valstybinių miškų urèdija (the State Forest Enterprise) [49]. The individual enterprises were combined in order to increase returns and promote more efficient operation, also addressing the challenges of transparency in the forestry sector. Currently, the State Forest Enterprise consists of 26 regional units. The private forest sector includes 250,100 private forest owners. Small-sized private forest properties are common in Lithuania, the average being 3.4 ha, unchanged since 2001.

Wood markets also changed considerably after the restoration of independence. Due to the emergence of the free wood market, exports of timber expanded. Previously, $1-2 \mathrm{~mm}^{3} \mathrm{yr}^{-1}$ of wood was imported from Russia; currently, a considerable amount of wood is exported. Demand, supply and other market factors now drive round-wood prices. There has been a trend towards increased wood removal from the forest, with harvesting increasing from $4 \mathrm{~mm}^{3}$ in 1990 to $7 \mathrm{~mm}^{3}$ in 2016 [46]. The harvesting level is still less than half the annual increment (see Table 2) and conforms to the restrictions of the Law on Forests [29], which indicates that the total volume of all annual forest cuttings cannot exceed the gross annual tree increment.

Round-wood harvesting in state forests amounted to $3.9 \mathrm{~mm}^{3}$ in 2016 and $3.78 \mathrm{~mm}^{3}$ of round wood were sold $[30,46]$. In the same year, contractors harvested $75 \%$ of the timber produced in state forest enterprises. The volume from final harvest in state forests was $2.7 \mathrm{~mm}^{3}$, 
amounting to $70 \%$ of the total harvest and private forest owners received cutting permits for $2.4 \mathrm{~mm}^{3}$ [46].

We conclude that the overall situation in the Lithuanian forests is favourable. The growth of forests far exceeds the harvest. Forests biomass resources make it possible to harvest potentially more biomass for energy. Forest land ownership is shared almost equally by the state and private owners whose individual holdings are small with limited resources available to manage their forest and trade the wood produced.

\section{Biomass supply for energy from the forestry sector}

The rate of growth of forests is obviously a key factor in determining the quantities of forest biomass that can be sustainably supplied from forests. Forest biomass for energy is an important part of the forestry and renewable energy sectors in Lithuania. Forest biomass comprises over $80 \%$ of total plant biomass in Lithuania [50]. The amount of biomass per capita in Lithuania is one of the highest in the EU. Consumption of forest biomass for energy production has significantly increased in Lithuania since about 2000. However, biomass available for energy production is still underused and the supply of firewood, logging residues, woody biomass from pre-commercial harvesting and short rotation plantations, and waste from the wood processing industry could be increased without exceeding the increment [51].

According to the Department of Statistics of Lithuania, $3.9 \mathrm{~mm}^{3}$ of firewood and industrial wood waste were used for energy production in 2009. In the absence of restrictions on removals, about $2.5 \mathrm{~mm}^{3}$ of logging residues could be produced annually from final clear cuts. However, technical capacity (harvesting equipment) and environmental regulations reduce this amount to 0.75 $\mathrm{mm}^{3}$ [52].

Although the extraction of logging residues from final clear cuts is more economic, residues could also be extracted for energy use from pre-commercial thinning of young stands, potentially generating about $0.4 \mathrm{~mm}^{3}$ of such biomass every year. However, producing chips from pre-commercial thinning is too expensive currently and so is not done in practice.

The rapid development in cultivation of short rotation plantations in Lithuania since before 2000 has been mainly driven by international companies [53]. Data from the National Paying Agency of the Ministry of Agriculture show that the total area of established short rotation plantations (including willows and other woody species) has steadily increased, reaching more than 3.8 Mha in 2018 (Table 3). Mean annual biomass increment in commercial Lithuanian plantations varies from 0.2 to $7.6 \mathrm{mg} \mathrm{ha}^{-1} \mathrm{yr}^{-1}[54,55]$.

Fast-growing grey alder stands are of specific interest for energy use in Lithuania [57]. Such stands occupy 121600 ha (5.9\% of the total forest area), and their growing stock amounted to $17 \mathrm{~mm}^{3}$ (4.3\% of the total growing stock) in 2016 [46]. With a 30-year rotation, more than $0.5 \mathrm{~mm}^{3}$ of grey alder biomass could be harvested annually. Since about 2000, state forest enterprises have offered an increasing amount of logging residues from grey alder stands to consumers and the current consumption of this biomass for energy is about $0.16 \mathrm{~mm}^{3} \mathrm{yr}^{-1}$.

Approximately $0.26 \mathrm{~mm}^{3}$ of logging residues are generated and sold annually from harvesting operations in state forests (Table 4). Data on production and sales of logging residues from private forests are not available.

The State Forest Enterprise plans to increase the supply of forest biomass for energy to $0.367 \mathrm{~mm}^{3}$ in 2019 and to $0.500 \mathrm{~mm}^{3}$ in 2023 [31]. Forest biomass, as a raw material for heat production, is competitive due to the significantly (2-3 times) lower price, compared to the main alternative which is natural gas (Fig. 5).

In summary, forest biomass use for energy production has expanded in Lithuania since about 2000, and its price is no more than half that of natural gas. However, forest biomass available for energy production is underused. Current logging technologies are not yet focused on the production of forest biomass for energy and the cost of harvesting biomass is too high and unprofitable for forest owners, especially in privately owned forests. These issues should have a higher profile at the State level, with shared responsibilities in seeking new approaches to common forest management practices as well as addressing the goal to increase forest biomass production for energy.

\section{Ecological constraints on forest biomass use for energy}

In order to minimise the risk of using unsustainable forest biomass for energy production, biomass harvesting should be carried out in accordance with the principles of sustainable forest management with special attention

Table 3 Short rotation plantation areas established with EU structural funds, 2007-2018 [56]. Crops like willow (Salix spp.) and poplar (Populus spp.) are grown in 3 to 5 year rotations

\begin{tabular}{|c|c|c|c|c|c|c|c|c|c|c|c|c|}
\hline & 2007 & 2008 & 2009 & 2010 & 2011 & 2012 & 2013 & 2014 & 2015 & 2016 & 2017 & 2018 \\
\hline Declared area, ha & 260 & 375 & 492 & 556 & 951 & 1097 & 1755 & 2484 & 2542 & 3453 & 3765 & 3860 \\
\hline
\end{tabular}


Table 4 Sales of logging residues (branches, tops, bark) produced in state forests, 2006-2017 [31, 46].

\begin{tabular}{|c|c|c|c|c|c|c|c|c|c|c|c|c|}
\hline & 2006 & 2007 & 2008 & 2009 & 2010 & 2011 & 2012 & 2013 & 2014 & 2015 & 2016 & 2017 \\
\hline Volume of residues sold, $\mathrm{mm}^{3}$ & 0.076 & 0.057 & 0.072 & 0.080 & 0.075 & 0.155 & 0.170 & 0.245 & 0.263 & 0.251 & 0.248 & 0.260 \\
\hline
\end{tabular}

given to the protection of landscapes, biodiversity, carbon stocks and nutrients $[18,20]$.

As pressure to produce forest biomass for heat and electricity in Lithuania increases, concern also increases over environmental impacts, including long-term site productivity and the future yields of forests. Different types of forest biomass are used for energy production in Lithuania, and such use is expected to become even more economically attractive in the future [58]. The impacts of intensified harvesting could lead to a need for mitigation of ecological risks, in order to maintain sustainable forest management. At the local level, forest biomass harvesting must already comply with formal environmental requirements in final fellings, including protection of soil, ground vegetation, understory, and biodiversity [33]. The formal requirements also include that significant loss of essential plant nutrients from forest soils should be avoided. This can be addressed, for example, by recycling wood ash back to the forest rather than dumping it in landfills as often happens, and as a way of sustainably managing waste products from forest energy.

The Regulations for Forest Fellings [33] include several rules for forest harvesting to ensure forest management remains ecologically sustainable under enhanced use of forest biomass for energy. The regulations allow forest fuel extraction to be integrated with other harvest operations if forest soil moisture and fertility conditions permit. Logging residues can be removed from the site, piled along skid trails or in stacks, or spread after crushing at the site, but they may not be burned at the cutting site. Forest residues can be extracted from clear cut sites for energy use or other purposes using skid trails. Mechanical equipment travel need not be confined to skid trails when the ground is frozen or on sites with mineral soils of normal moisture regime, if the understory is preserved. These conditions avoid soil compaction by mechanical equipment. To conserve biodiversity, a minimum of $5 \mathrm{~m}^{3} \mathrm{ha}^{-1}$ of logging residues must be left on clear cuts and the same volume of living 'biodiversity trees', mostly of broadleaved species. The rules allow stump extraction in final harvest areas in commercial forests outside of protection zones, provided prospective understory trees are saved and soil conditions suitable for regeneration are prepared. However, stump extraction is not allowed on forest sites with highly oligotrophic soils, on moderately moist vulnerable mineral soils and permanently very wet mineral soils, on undrained peatland soils, or on slopes greater than $15^{\circ}$.

Lithuanian studies on nutrient balances in intensively harvested Scots pine stands showed that the removal of nutrients from the forest would be 2 to 3 times more when removing all aboveground biomass-as might be done to supply biomass for energy from thinnings and from sanitary and final fellings - than if only stems were harvested [59-61]. However, during the 100-year rotation of such stands, the nutrient influx (especially $\mathrm{N}$ and $\mathrm{K}$ ) from

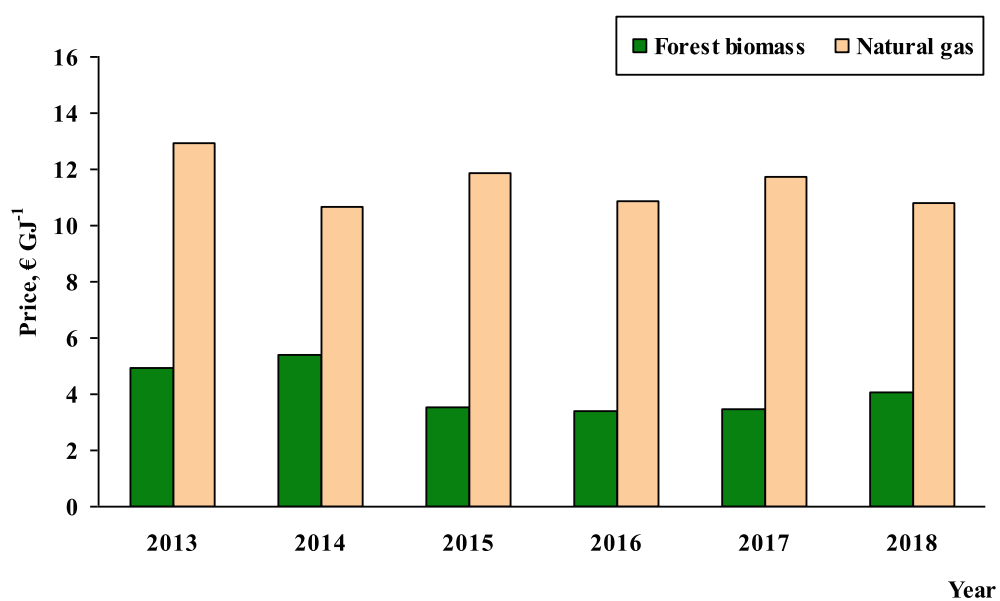

Fig. 5 Comparison of prices (in $€ \mathrm{GJ}^{-1}$ ) of the two raw materials—forest biomass and natural gas—used in heat production. Data source: Strategy of State Forest Enterprise Activity 2019-2023 [31] 
litterfall would be 4 to 10 times greater than the nutrient removals for energy use. Losses of $\mathrm{N}, \mathrm{P}, \mathrm{K}, \mathrm{Ca}$ and $\mathrm{Mg}$ would also be partly compensated by atmospheric depositions. For the extraction of forest biomass for energy to be sustainable, it is recommended that removed nutrients are recycled to the forest.

In recent years, over $30 \mathrm{kt}$ of forest biomass ash have been produced annually in Lithuania [62]. This makes wood ash handling one of the main challenges to the forest biomass for energy sector. This question requires more attention by authorities responsible for the control of environmental pollution together with the related topic of nutrient balances in the forest. The recycling of nutrients to the forest could be achieved by recycling wood ash which retains most of the plant macronutrients $(\mathrm{K}, \mathrm{P}, \mathrm{Ca}, \mathrm{Mg})$ other than nitrogen, which is volatilised during combustion. In order to be classified as compensatory fertiliser and allow it to be recycled to the forest, ash must contain an appropriate quantity of plant macronutrients and have a minimal effect on forest ecosystems. However, rather than being classified as a fertiliser, wood ash can often be classified only as a waste product containing very low quantities of plant nutrient elements, as well as relatively high quantities of toxic metals such as $\mathrm{Cd}$, As, $\mathrm{Cr}, \mathrm{Hg}, \mathrm{Ni}$ and $\mathrm{Pb}$. Such ash could cause a negative impact in the soil, if added in higher amounts. Plants extract these toxic elements from the soil, or they may be leached into the groundwater [63]. In addition, radionuclides, especially ${ }^{137} \mathrm{Cs}$ and ${ }^{90} \mathrm{Sr}$, may diminish wood ash quality. These radionuclides were deposited in the western part of Lithuania and in extensive regions of Belarus after the Chernobyl nuclear power plant accident on 6 April 1986 [64, 65].

The effects of compensatory wood ash fertilisation on different components of the forest ecosystem were studied in 2001-2005 in a long-term field experiment. The study had six treatments: (a) untreated control, (b) $1.25 \mathrm{t}$ ha $^{-1}$ wood ash applied, (c) $2.5 \mathrm{t} \mathrm{ha}^{-1}$ wood ash applied, (d) $5.0 \mathrm{t} \mathrm{ha}^{-1}$ wood ash applied, (e) $2.5 \mathrm{t} \mathrm{ha}^{-1}$ wood ash

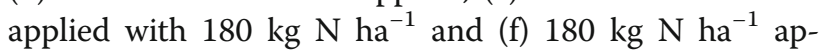
plied as mineral $\mathrm{N}$ fertiliser [56-58]. The results showed that the heaviest application of wood ash did not cause significant changes in chemistry (including heavy metals) in the soil, soil solution or vegetation [66-70]. Shortterm chemical changes were found in the organic layer/ forest floor, i.e. increased $\mathrm{pH}$ and total concentrations of nutrients.

The 'Recommendations for compensating wood ash fertilisation' published in 2006 include the main requirements of the current legislation [62]. Depending on the amount of nutrients removed in forest biomass, ecological requirements (see the next paragraph), nutrient concentrations in the ash, and concentrations of any toxic heavy metals which may be present, between 3 and
$5 \mathrm{t} \mathrm{ha}^{-1}$ of wood ash, or up to $7 \mathrm{tha}^{-1}$ with additional $\mathrm{N}$ fertilisers (70-120 $\mathrm{kg} \mathrm{N} \mathrm{ha}^{-1}$ ) may be applied to the forest over one rotation (approximately 100 years) [62]. Wood ash application is limited to commercial forests (IV forest group) on sites of normal soil moisture, with priority given to stands or clear cuts where all logging residues have been removed. Over one rotation, the recommendation is for two applications of between 1.5 and $3.5 \mathrm{t} \mathrm{ha}^{-1}$ of forest biomass ash, the first at the time of thinning, the second, of ash combined with $\mathrm{N}$ fertilisers, when stands are at the medium stand development stage or close to final harvesting age.

The 'Recommendations for compensating wood ash fertilisation' [62] include some additional environmental requirements: wood ash can be applied in drained or naturally draining peatland soils; ash cannot be applied in 20\% of forest areas in order to preserve biological diversity; ash cannot be applied closer than $50 \mathrm{~m}$ from surface water bodies (lakes, streams, drainage ditches) or poorly drained sites; ash fertilising cannot be undertaken on snow cover because of the risk of chemical ash particles leaching out in spring runoff.

A detailed study was conducted to update allowable concentrations of trace metals in dry wood ash under local environmental conditions in Lithuania. The study showed that allowable concentrations of some heavy metals $(\mathrm{Cd}, \mathrm{Cu}$ and $\mathrm{Hg})$ in wood ash in some Nordic countries are several times higher than are found in wood ash in Lithuania (Table 5). Therefore, based on the earlier 'Recommendations for compensating wood ash fertilisation' and updated data on wood ash quality, the legal 'Regulations for wood ash disposal and use' were adopted in 2011 [32]. The Regulations do not permit the recycling in the forest or on agricultural land of contaminated wood ash containing residues from the paper and furniture industries.

Some gaps in the knowledge and regulation of the environmental impact of wood ash recycling still exist. For example, the regulations do not include any restrictions on contents of dioxins and radioactive compounds $\left({ }^{137} \mathrm{Cs},{ }^{90} \mathrm{Sr}\right)$. There are no detailed studies on the impact of wood ash application on fastgrowing agricultural crops or short rotation plantations. Also, more detailed experimental data are still needed on impacts of extremely high ash application rates and on the application of stabilised wood ash. Even if wood ash application in the forest is still not being broadly practised, it could sometimes provide an alternative to other means of ash disposal, such as in forest road construction.

Based on national regulations, studies and other scientific evidence, key problems or potential risks exist for 
Table 5 Comparison of maximum and actual concentrations of trace elements $\left(\mathrm{mg} \mathrm{kg}^{-1}\right)$ in dry wood ash [32, 71], unpublished results] in Nordic countries and Lithuania

\begin{tabular}{|c|c|c|c|c|c|}
\hline Country & Denmark & Finland & Sweden & Lithuania & Lithuania \\
\hline Application & $\begin{array}{l}\text { Agriculture/ } \\
\text { Forestry }\end{array}$ & $\begin{array}{l}\text { Agriculture/ } \\
\text { Forestry }\end{array}$ & Forestry & - & Agriculture/Forestry \\
\hline Status & Legislation, 2006 & Legislation, 2007 & $\begin{array}{l}\text { Recommendations, } \\
2007\end{array}$ & $\begin{array}{l}\text { Agrochemical Research Lab, } \\
\text { LAMMC* }^{*}\end{array}$ & $\begin{array}{l}\text { Regulations for wood ash disposal } \\
\text { and use }\end{array}$ \\
\hline Arsenic (As) & - & $25 / 30$ & 30 & $\sim 4$ & 3 \\
\hline $\begin{array}{l}\text { Cadmium } \\
\text { (Cd) }\end{array}$ & $5 / 15$ & $15 / 17.5$ & 30 & $9-11$ & $5 / 3$ \\
\hline $\begin{array}{l}\text { Chromium } \\
(\mathrm{Cr})\end{array}$ & 100 & 300 & 100 & - & $30 / 20$ \\
\hline Copper (Cu) & - & $600 / 700$ & 400 & $200-250$ & $200 / 100$ \\
\hline Mercury (Hg) & 0.8 & 1.0 & 3 & $<0.5$ & 0.2 \\
\hline Nickel (Ni) & $30 / 60$ & $100 / 150$ & 70 & $30-35$ & $30 / 20$ \\
\hline Lead (Pb) & 120 & $100 / 150$ & 300 & $\sim 60$ & $50 / 40$ \\
\hline Zinc (Zn) & - & $1500 / 4500$ & $1000-7000$ & $2500-3500$ & $1500 / 1000$ \\
\hline References & [71] & [71] & [71] & Unpubl. & [32] \\
\hline
\end{tabular}

*Data show the measured maximum concentrations of trace elements in dry wood ash from energy plants in Lithuania

intensive forest biomass use for energy. The production and use of forest biomass for energy can lead to adverse environmental impacts on soil and biodiversity. The removal of plant nutrients by intensive harvesting of forest biomass for energy can cause negative nutrient balances in soil but could be compensated by recycling forest biomass ash to the forest.

\section{Future perspectives}

Since 2010, Lithuania has undergone a fundamental energy sector transformation driven by common EU and national policies as well as by European Commission (EC) ambitions. According to Kim and Wilson [72], the European Commission stated the ambition to achieve a fundamental transformation of Europe's energy system. The EC's systematic perspective on innovation emphasises the influence that wider social, institutional and economic processes have on innovation outcomes. In 2008, the Strategic Energy Technology (SET) Plan was launched to provide strategic planning and coordination of energy research and innovation activities within the EU. The SET plan was designed to support EU policy objectives on climate change, energy efficiency, and renewable energy, as well as energy security, energy union, growth, jobs, and global competitiveness. The SET plan was implemented through a range of activities. In 2015, the EC proposed a revised SET plan that was more targeted and used a whole-systems approach to ensure better integration across sectors and technologies [73]. This EU policy laid out the fundamental basis for further transformations of the energy sector in Lithuania and indirectly encouraged the development of forest biomass for energy production in the future through technological change.

The technological transformation of the energy sector is closely linked to other EU policies. The EU has set ambitious climate and energy targets for 2030, including an EU-wide target for renewable energy of at least $27 \%$ of final energy consumption [74]. The future prospects for renewables in the energy sector in Lithuania, as in other EU countries, should be promising, since they can deliver higher security of supply, lower costs and lower $\mathrm{CO}_{2}$ emissions. In order to increase awareness of the possibilities with district heating, the current district heating technology must also be enhanced, and the introduction of new technologies should be prioritized. The relevant local conditions and resources for energy must be quantified at national level in order to have a complete picture [39]. The national goal in Lithuania is to produce heat with zero $\mathrm{CO}_{2}$ net emissions by 2050 , i.e. to produce heat from renewables only [75]. Lithuania's energy strategy promotes the development of district heating systems and cogeneration by financial support and incentive mechanisms. Because of its established national energy policy, the Lithuanian district heating sector has already accumulated many new ideas and much experience in the sector to be shared with other countries seeking to reduce environmental impacts and ensure efficient district heating. Lithuania, together with other EU Member States, faces a challenge to exploit the full potential of biomass and to contribute to the decarbonisation of the economy through its uses for materials and energy. It should promote 
greater sustainable mobilisation of existing timber and agricultural resources as well as the development of new forestry and agriculture production systems, provided that sustainability and GHG emissions saving criteria are met [20]. Based on this document, the main challenges in the next years will be to increase sustainable use of renewables, including forest biomass for energy, as it is a crucial element in combatting climate change, protecting the environment and reducing energy dependency, as well as contributing to the technological and industrial leadership of Lithuania and the EU. At the national level, it should also provide new jobs and growth in rural areas. Regarding specific policy objectives, monitoring under existing EU and national legislation and reporting should take place within the objectives of biomass use for energy to mitigate climate change, reduce impacts on biodiversity, soil, water and air, and promote efficient uses of biomass for energy, including electricity and heating, and monitoring of prices of raw wood materials [21].

EU bioeconomy trends will also be driving the intensive use of forest biomass for energy production in the future. In the Lithuanian bioeconomy development feasibility study prepared in 2017, the forest bio-based sector (forestry and logging, production of wood, paper and furniture) is mentioned as the second largest sector, after the food sector, of the Lithuanian bioeconomy [76]. The potential for development of this sector has been increased by the EU provision that bioenergy will remain the main renewable energy source in the pursuit of climate and energy goals for 2020-2030. Though the use of forest biomass is limited by environmental goals prohibiting or limiting economic activities, the wood resources in Lithuania are still used traditionally and for energy. Due to their attractive price, the sufficiency of local resources, and low emissions, forest biomass should remain the principal energy source in Lithuanian district heating systems. For Lithuania, the increased use of renewables in the energy sector in place of natural gas means national energy independence. Therefore, forest biomass for energy is considered to have a high potential to remain one of the most important local renewable energy resources in the future [77].

Favourable energy policies at EU and national levels do not, by themselves, ensure future sustainable use of forest biomass for energy production in Lithuania. The production of forest biomass for energy is influenced by a number of factors. One key challenge in increasing the use of bioenergy in the future is to maintain sustainable production. With the revised Renewable Energy Directive (EU 2018/
2001) [20], sustainability criteria have been adopted for agricultural and forest biomass. The sustainability criteria address environmental aspects such as soil quality, land use and biodiversity. The GHG emissions reduction criteria ensure that bioenergy is only used if it achieves high emission savings compared to fossil fuels. The use of forest biomass for energy production is highly dependent on the potential amount of biomass in the forests in general and on factors limiting utilization. In 2014, calculations were made of the biomass potentials from forests in EU28 countries for 2020 and 2030; for Lithuania, this biomass potential is assessed to be $12.26 \mathrm{~mm}^{3}$ and $13.40 \mathrm{~mm}^{3}$ for those 2 years, respectively [78]. However, in a real situation, this amount of estimated potential forest biomass decreases due to certain factors. Researchers have analysed how the increase in area of protected forests impacts the biomass potentials. Three factors were seen as decreasing forest biomass potentials: increase in protected areas, retained trees, and strict environment criteria. The Report [78] indicated that stricter environmental constraints-compared to the reference mobilisation potential-include no residue removal from less productive poor soils and a maximum of $70 \%$ residue removal on other soils. For the low mobilisation which had the strictest environmental constraints, stump extraction and application of fertiliser to mitigate detrimental effects of removing logging residue on the soil were not permitted.

An excellent illustration of the regulation and limitations of the use of forest biomass for energy production are the EC non-binding recommendations on sustainability criteria for biomass [79]. These recommendations are meant to apply to energy installations of at least $1 \mathrm{MW}$ thermal heat or electrical power. The recommended criteria include key directions: restricting the use of biomass from land converted from forest and other high carbon stock areas, as well as highly biodiverse areas; ensuring that biofuels emit at least 35\% less GHGs than fossil fuels over their lifecycle (cultivation, processing, transport). For new installations, this amount rose to $50 \%$ in 2017 and 60\% in 2018; favouring national biofuel support schemes for highly efficient installations; and encouraging monitoring the origin of all biomass consumed in the EU to ensure its sustainability. The issues mentioned could impact Lithuanian energy sector development.

The future intensity of utilization of forest biomass for energy production will also depend on alternative uses of the forest biomass and competition with other types of fuels in Lithuania. Pang et al. noted that the current technological processes in forest harvesting 
and wood processing create several distinct types of forest bioenergy feedstock [77]. Firstly, harvested stemwood can be consumed for fuel directly, for example, as solid-piece firewood. This is primarily stemwood that has no alternative material use due to technical quality flaws (too small, rot, form defects), but it could also be some fraction of the industrial wood (otherwise used in construction, for sawmilling, veneer production, particle board production or as pulpwood). Secondly, the proportion of industrial wood from harvested stemwood affects the amounts of industrial waste produced (sawdust, wood chips and pulpmill by-products). Thirdly, logging residues (tops, branches and stumps) left in the forest could be collected and used. Lastly, there is the recycled wood that comes from demolishing old structures, recycling furniture, wooden packaging, etc. Within the energy pathways, a steep increase in biomass consumption is envisaged between 2040 and 2050. This can be explained by the alignment of RES targets with the EU Energy Roadmap, along with a gradual increase in energy demand and a changing technology structure due to obsolescence of the current power plants, which makes new investments in energy generation from biomass more attractive [77].

Sustainable use of forest biomass for energy production involves a number of aspects. One is sustainable forest biomass production and delivery to the consumer's system. There is no sustainable system for supplying forest biomass from local resources in Lithuania. Increasing concerns have been expressed about the potential sustainability risks associated with intensive use of biomass for energy, including those stemming from imports from third countries [22]. As the demand for solid biomass for energy production is likely to continue to grow post2020, Lithuania faces the challenge of adapting to differently functioning, state-regulated markets in neighbouring Eastern countries from which forest biomass is imported.

\section{Conclusions}

Forest biomass is a strategically important renewable resource for the energy sector in Lithuania. The political and economic goal of gaining independence from natural gas, which was supplied from a single source at a very high price, encouraged the transformation of the sector. Today, renewables are used economically and effectively for energy production and the energy price for end consumers has been significantly reduced. Further reduction in imports of primary fossil energy sources is certainly possible but not desirable. The National Energy Independence Strategy ambitiously indicates that the share of renewables in the total final energy consumption will reach $45 \%$ by 2030 , and, in the long-term, goals have been set for the Lithuanian energy sector to be fossil-fuel free by 2050. The increased use of renewables in the energy sector in place of natural gas means national energy independence for Lithuania.

A favourable legal network has been created for the development of biomass energy, which has facilitated rapid and efficient restructuring of the energy sector since 2010, especially in district heating. However, the legislation does not provide long-term guidelines for the development of renewable energy, which would allow investors to forecast the needed expansion of the sector and apply for the needed financial support from EU Structural Funds.

The replacement of natural gas by renewable resources, especially forest biomass used in heat production, has resulted in a significant price reduction for end consumers. The reduction in central heat prices was mainly influenced by the increased use of locally available forest biomass and the emergence of the biofuel exchange, which is one of the main market instruments licensed by the National Control Commission for Prices and Energy for the exchange of energy resources within the Baltic region and promotes the use of biomass for heat production. Since 2016, all biomass for energy production has been purchased on the biomass exchange. It is legally regulated but allows biomass to be bought outside the exchange if the price is lower than on the exchange. The established system of energy biomass auctions ensures a lower price and prevents unjustified price increases. The Lithuanian forest biomass market is strongly influenced by cheaper wood chips supplied from neighbouring Belarus.

Lithuania must consider the ecological impacts of increased forest biomass use for energy. Intensive forest biomass harvesting must be balanced with the requirements of sustainable forest management. Specifically, nutritional balance and soil fertility can be ensured without undesired environmental impacts through the strict regulatory mechanism now in place which allows compensatory wood ash recycling in commercial forests.

Recent work has shown that the Lithuanian energy sector is moving towards a more sustainable development, with several strengths of the structures in place today, which include abundant forest biomass resources from land under sustainable forest management, appropriate legislation and supportive financial instruments in the district heating sector. The most critical weakness for sustainable development is the high amount of imported forest biomass for energy from Belarus. 


\section{Appendix}

Table 6 Overview of legislations and financial instruments for energy sector formation and boosting of forest biomass usage in energy production in Lithuania

\begin{abstract}
Reference
Legal regulatory acts formatting energy sector policy:

Renewable Energy Directive (2009/28/EC) of the European Parliament and of the Council of 23 April 2009 on the promotion of the use of energy from renewable energy sources (RES) and amending and subsequently repealing Directives 2001/77/EC and 2003/30/EC [19]. The directive established an overall policy for the production and promotion of energy from RES in the EU. It required the EU to fulfil at least $20 \%$ of its total energy needs with renewables by 2020 - to be achieved through the attainment of individual national targets. All EU countries must also ensure that at least 10\% of their transport fuels come from RES by 2020.
\end{abstract}

Renewable Energy Directive (EU) 2018/2001 of the European Parliament and of the Council of 11 December 2018 on the promotion of the use of energy from RES [20]. The directive aimed at keeping the EU a global leader in renewables and helping the EU to meet its emissions reduction commitments under the Paris Agreement. The new directive establishes a new binding renewable energy target for the EU for 2030 of at least 32\%, with a clause for a possible upwards revision by 2023.

Most of the other new elements in the new directive need to be transposed into national law by Member States by 30 June 2021 .

The main energy sector development policy is described in the National Energy Independence Strategy [13], which has been approved by Resolution No XI-2133 of the Seimas (Parliament) of the Republic of Lithuania of 26 June 2012 and amended in the year 2018. The main goal of this Strategy is to ensure Lithuania's energy independence before the year 2020 by strengthening Lithuanian's energy security and competitiveness. The purpose of the National Energy Independence Strategy is to define the main objectives of the Lithuanian state in the energy sector and to set national targets for the implementation of strategic initiatives until 2020, as well as to lay down guidelines for the development of Lithuania's energy sector until 2030 and until 2050. The implementation of the Strategy is coordinated by the Ministry of Energy and specified in the Strategy Action Plan.

The Law on Energy of the Republic of Lithuania [24]. This Law establish the main aims of energy activities in the Republic of Lithuania as well as the legal basis of state management, regulation, supervision and control of the energy sector, the general criteria, conditions of and requirements for public relations, and the main areas of state energy policy.

The Law on the Heat Sector of the Republic of Lithuania [26]. This Law shall regulate State management of the heat sector, the activities of the heat sector entities, their relations with heat consumers, their interrelationship and responsibility. Objectives of the Law: (1) to ensure reliable and high-quality supply of heat to heat consumers at minimum costs; (2) to ensure by law effective competition in heat sector; (3) to defend the rights and legitimate interests of heat consumers; (4) to increase the efficiency of heat production, transfer and consumption; (5) when producing heat, to increase the use of indigenous fuel, biofuel and renewable energy resources; (6) to reduce the negative impact of the heat sector on the environment.

Legal regulatory acts boosting biofuel usage in energy productions

The National Strategy for the Development of Renewable Energy Sources [23], as approved by Resolution No 789 of the Government of the Republic of Lithuania of 21 June 2010 approving the National Strategy for the Development of Renewable Energy Sources. The main objective: by increasing the share of renewable energy resources in the country's energy balance, to meet energy needs in the electricity, heating and transport sectors to an optimal extent using domestic resources, to phase out imported polluting fossil fuels, and thus to enhance energy security and energy independence and to contribute to international efforts in reducing greenhouse gas emissions. The 2010-2015 Plan of implementing measures for the National Strategy for the Development of Renewable Energy Sources, as approved by Order No 1-180 of the Minister for Energy of the Republic of Lithuania of 23 June 2010 approving the
Expected result

National overall target for the share of energy from RES in gross final consumption of energy in 2020 for Lithuania is $23 \%$.

In Lithuania, the overall objective for renewables is $45 \%$ for 2030, described as renewables share in the final energy consumption- $45 \%$, in central heating sector- $90 \%$, in transport sector-15\%, in the final electricity consumption - $45 \%$ and renewables share in electricity generation-70\%.

Lithuania's energy independence before the year 2020 by strengthening Lithuanian's energy security and competitiveness.

Secure and reliable energy supply. Balanced and sustainable developed the energy sector. Reduced the negative impact of energy activities on the environment. Promoted the use of indigenous and renewable energy sources.

Ensured reliable and high quality supply of heat to heat consumers at minimum costs, effective competition in heat sector. Increased the use of indigenous fuel, bio fuel and renewable energy resources. Reduced the negative impact of the heat sector on the environment.

Increased use of RES. The share of RES in the country's gross final consumption of energy would reach at least 23\% in 2020. 
Table 6 Overview of legislations and financial instruments for energy sector formation and boosting of forest biomass usage in energy production in Lithuania (Continued)

\begin{tabular}{|c|c|}
\hline Reference & Expected result \\
\hline $\begin{array}{l}\text { Plan of implementing measures for the National Strategy for the Develop- } \\
\text { ment of Renewable Energy Sources. }\end{array}$ & \\
\hline $\begin{array}{l}\text { Law on Energy from Renewable Sources of the Republic of Lithuania [25]. } \\
\text { This law establish the legal basis for state administration, regulation, } \\
\text { supervision and control of the renewable energy sector of the Republic of }\end{array}$ & $\begin{array}{l}\text { Increased use of RES. The share of RES in the country's gross final } \\
\text { consumption of energy would reach at least } 23 \% \text { in } 2020 \text { and this share } \\
\text { would be further increased. }\end{array}$ \\
\hline
\end{tabular}
supervision and control of the renewable energy sector of the Republic of would be further increased. Lithuania and organisation of activities in the renewable energy sector, also stipulate the state regulation and supervision of operations of energy grid operators, producers of energy from RES and their relations with controlling authorities. The objective of this law is to ensure the coherent development of energy use from RES, to promote further development and the introduction of new technologies, and the consumption of energy produced, in particular with regard to the international commitments of the Republic of Lithuania, the objectives of environmental protection, saving of fossil energy sources, reduction of reliance on fossil sources of energy and energy import and other State energy policy objectives, taking into consideration energy security and reliability requirements and the principles of the protection of consumer rights and lawful interests in the accessibility, adequacy and sufficiency of RES.

National Forestry Sector Development Programme 2012-2020 [27]. The purpose of the Programme is to implement the long-term forestry strategy of Lithuania that would be consistent with the policy of other related areas, based on the traditions of the country and the requirements of European Union legal norms, international conventions, resolutions, agreements and programmes, and determine the objectives and tasks for the development of the forestry sector for the period until 2020. One of the tasks of Programme is to balance the volume of thinnings, sanitary and final fellings of forests, and increase the volume of non-merchantable timber and forest felling residues used for biofuel production. One of the target values of the programme is that volume of forest felling residues and non-merchantable timber used for biofuel production will be increase and $500,000 \mathrm{~m}^{3}$ will be produced in 2020 .

Financial instruments boosting usage biofuel in energy productions:

The 2007-2013 and 2014-2020 Lithuanian Rural Development Programmes [28]. Measures included in the 2007-2013 Lithuanian Rural Development Programme promote the use of RES. Aid intensity varies from 40 to $65 \%$ of eligible project costs. The 2014-2020 Lithuanian Rural Development Programme, as approved by Decision No C (2015) 842 of the European Commission of 13 February 2015. One of the activities supported under Measure 'Modernisation of agricultural holdings' of the Lithuanian Rural Development Programme for 2007-2013 is the planting of short rotation coppice. Aid to the planting of short rotation coppice may not exceed $434 €$ per hectare. The aid intensity is up to $50 \%$. Aid for the activity area 'Planting of short rotation coppice' may be applied for by natural and legal persons lawfully managing agricultural land. Measures included in the 2014-2020 Lithuanian Rural Development Programme promote the use of felling waste and biogas. Aid intensity varies from 40 to $65 \%$ of eligible project costs.

Investments in forestry technologies (measure of the 2014-2020 Lithuanian Rural Development Programme) facilitating the supply and use of RES, by-products, wastes, residues and other non-food raw material, for the purposes of the bioeconomy.

Support for investments in agricultural holdings. Activities supported under the measure: (1) production of biogas at a livestock farm from farm waste. Biogas and heat and power produced can be used only for the needs of the holding; (2) cultivation of short rotation coppice. 


\section{Abbreviations}

EU: European Union; EC: European Commission; RES: Renewable energy sources; GHG: Greenhouse gas; COP: Conference of the Parties; IPCC: Intergovernmental Panel on Climate Change; BALTPOOL: Baltic region energy resources exchange; SET: Strategic Energy Technology; FSC: Forest Stewardship Council; PEFC: Programme for the Endorsement of Forest Certification; VAT: Value-added tax

\section{Acknowledgements}

The paper presents the findings obtained through the long-term research programme 'Sustainable Forestry and Global Changes' implemented by the Lithuanian Research Centre for Agriculture and Forestry. The studies of Scots pine aboveground measurements and the wood ash field experiment were carried out under the EU project 'Wood for energy - a contribution to the development of sustainable forest management (WOOD-EN-MAN, QLK5-CT2001-00527)', 2001-2005. The study of maximal values of ecotoxic metals and the database was prepared together with the researchers from the Agrochemical Research Laboratory (LAMMC)

\section{Authors' contributions}

IVK and DL conceived the study (study design, objectives and methodology), analysed and interpreted the literature and statistical data, coordinated the work and revised the paper. SM contributed to economic data and legislation analysis. LB participated in the literature and data analysis. KA contributed to the analysis of ecological issues. All authors read and approved the final manuscript.

\section{Funding}

This research received general funding from the Lithuanian Research Centre for Agriculture and Forestry (LAMMC). The funding bodies had no impact on the design of the study, data interpretation or the writing of the manuscript.

\section{Availability of data and materials}

Not applicable.

\section{Ethics approval and consent to participate}

Not applicable.

\section{Consent for publication}

Not applicable.

\section{Competing interests}

The authors declare that they have no competing interests.

Received: 6 March 2019 Accepted: 15 November 2019

Published online: 05 December 2019

\section{References}

1. Roberts J, Bodman F, Rybski R (2014) Community power: model legal frameworks for citizen-owned renewable energy. Community Power and ClientEarth, London http://www.clientearth.org/reports/community-powerreport-250614.pdf.

2. UN Global Compact (2015) Global business leaders at the Business \& Climate Summit send a clear message to national and international policymakers: 'We want a global climate deal that achieves net zero emissions - make it happen at COP21'. Press release (Paris: 21 May 2015). Available at https://www.unglobalcompact.org/news/1871-05-21-2015. Accessed 25 Feb 2019

3. Sapp M (2015) Lithuania parliament votes to scrap excise exemptions on biofuel blends. Biofuels Digest, 10 Dec 2015. Available at http://www. biofuelsdigest.com/bdigest/2015/12/10/lithuanian-parliament-votes-toscrap-excise-exemptions-onbiofuel-blends/.

4. REN 21 (2016) (Renewables) Global Status Report. Available at http://www. ren21.net/. Accessed 30 July 2018.

5. UN (2015) Paris Agreement. Available at https://unfccc.int/sites/default/files/ english_paris_agreement.pdf.

6. WBA (2016) (World Bioenergy Association) After COP 21 (Paris): FES 2030 Fossil Exit Strategy 2030 for Europe. Available at https://worldbioenergy.org/ uploads/Fossil\%20Exit\%20Strategy.pdf. .

7. IEAE (2004) (International Atomic Energy Agency). Energy supply options for Lithuania. A detailed multi-sector integrated energy demand, supply and environmental analysis. Available at https://www-pub.iaea.org/MTCD/ Publications/PDF/te 1408 web.pdf.

8. Gaubyte V (2017) Bioenergy in Lithuania: low prices, new jobs, clean environment. Lithuanian Biomass Energy Association LITBIOMA. Available at http://www.Ista.It/files/events/170321_Lenkai/Pranesimai/Litbioma\%20_\%2 OVilma\%20Gaubyte\%20_\%20Bioenergy\%20in\%20Lithuania\%20low\%2 Oprices\%20new\%20jobs\%20....pdf. .

9. EEA (2017) (European Environment Agency) Trends and projections in Lithuania 2017. Tracking progress towards Europe's climate and energy targets. Country fact sheet. Available at https://www.eea.europa.eu/ publications/trends-and-projections-in-europe-2017.

10. Williams A, Jones JM, Ma L, Pourkashanian M (2012) Pollutants from the combustion of solid biomass fuels. Prog Energy Combust Sci 38:113-137

11. Chen J, Li C, Ristovski Z, Milic A, Gu Y, Islam MS, Wang S, Hao J, Zhang H, He C, Guo H, Fu H, Miljevic B, Morawska L, Thai P, Lam YF, Pereira G, Ding A Huang X, Dumka UC (2017) A review of biomass burning: emissions and impacts on air quality, health and climate in China. Sci Total Environ 579: 1000-1034

12. Röder $M$, Thornley $P$ (2016) Bioenergy as climate change mitigation option within a $2{ }^{\circ} \mathrm{C}$ target-uncertainties and temporal challenges of bioenergy systems. Energy, Sustainability and Society 6:6

13. MEnergy (2018) (Ministry of Energy of the Republic of Lithuania). National Energy Independence Strategy of the Republic of Lithuania. Approved by the Seimas of the Republic of Lithuania on 21 June 2018. Available at https://enmin.Irv.It/uploads/enmin/documents/files/Nacionaline\%2 Oenergetines\%20nepriklausomybes\%20strategija_2018_EN.pdf. Accessed 30 Jan 2019.

14. Lindroos TJ, Lehtilä A, Koljonen T, Kofoed-Wiuff A, Hethey J, Dupont N, Vitina A (2018) Baltic Energy Technology Scenarios 2018. Nordic Council of Ministers. 164 p. Available at https://norden.diva-portal.org/smash/get/ diva2:1195548/FULLTEXT01.pdf. .

15. MEnergy (2017) (Ministry of Energy of the Republic of Lithuania). The vision of the Lithuanian energy sector: complete independence from fossil fuels by 2050. Available at https://enmin.Irv.lt/en/news/the-vision-of-thelithuanian-energy-sector-complete-independence-from-fossil-fuels-by-2050. Accessed 10 Feb 2019

16. Jovovic R, Simanavičienè Z, Dirma V (2016) Assessment of heat production savings resulting from replacement of gas with biofuels. Transform Bus Econ 16(1):34-51

17. Stupak I, Raulund-Rasmussen K (2016) Historical, ecological, and governance aspects of intensive forest biomass harvesting in Denmark. Wiley Interdisciplinary Reviews: Energy and Environment 5(5):588-610

18. Matthews R, Sokka L, Soimakallio S, Mortimer N, Rix J, Schelhaas M-J, Jenkins T, Hogan G, Mackie E, Morris A, Randle T (2014) Review of literature on biogenic carbon and life cycle assessment of forest bioenergy. Final Task 1 report, EU DG ENER project ENER/C1/427, 'Carbon impacts of biomass consumed in the EU'. Forest Research: Farnham. Available at: https:/ec. europa.eu/energy/sites/ener/files/2014_biomass_forest_research_report_. pdf. Accessed 15 Aug 2019.

19. Renewable Energy Directive (2009/28/EC). Directive 2009/28/EC of the European Parliament and of the Council of 23 April 2009 on the promotion of the use of energy from renewable sources and amending and subsequently repealing Directives 2001/77/EC and 2003/30/EC.

20. Renewable Energy Directive (EU) 2018/2001. Directive (EU) 2018/2001 of the European Parliament and of the Council of 11 December 2018 on the promotion of the use of energy from renewable sources.

21. EC (2016) Sustainability of Bioenergy. Accompanying the document. Proposal for a Directive of the European Parliament and of the Council on the promotion of the use of energy from renewable sources (recast). Commission staff working document impact assessment. COM(2016) 767 final; SWD(2016) 419 final. Available at: https://eur-lex.europa.eu/resource. html?uri=cellar:1bdc63bd-b7e9-11e6-9e3c-01aa75ed71a1.0001.02/DOC 1 \&format=PDF. Accessed 15 July 2019.

22. EC (2014) State of play on the sustainability of solid and gaseous biomass used for electricity, heating and cooling in the EU. Commission staff working document. Available at: https://ec.europa.eu/energy/sites/ener/ files/2014_biomass_state_of_play_.pdf. Accessed 15 Aug 2019.

23. MEnergy (2010) (Ministry of Energy of the Republic of Lithuania) National Strategy for the Development of Renewable Energy Sources and Action Plan. Available at http://www.ena.It/en/action_plan_lithuania en.pdf. Accessed 10 Feb 2019 
24. Seimas of the Republic of Lithuania (2002) Law on Energy of the Republic of Lithuania. No IX-884. New version of the Law from Jan 1, 2012. Available at https://e-seimas.Irs.lt/portal/legalAct/It/TAD/cc700b403c3f11e68f278e2f1 841 c088?jfwid=-g0zrz2ksv Accessed 10 Feb 2019 (in Lithuanian).

25. Seimas of the Republic of Lithuania (2011) Law on Energy from Renewable Sources of the Republic of Lithuania. No 62-2936. Available at https://eseimas.Irs.lt/portal/legalAct/lt/TAD/648259603c3b11e68f278e2f1841 c088?jfwid=rivwzvpvg Accessed 10 Feb 2019.

26. Seimas of the Republic of Lithuania (2003) Law on the Heat Sector of the Republic of Lithuania. No IX-1565. As last amended on 17 May 2018 No XIII1168. Available at https://e-seimas.Irs.lt/portal/legalAct/lt/TAD/d145d7d0b2 8511e8aa33fe8f0fea665f?jfwid=11 dyhejazj.

27. ME (2012) (Ministry of Environment of the Republic of Lithuania) The National Forestry Sector Development Programme 2012-2020 [Nacionaline mišku ükio sektoriaus plètros 2012-2020 metu programa]. Available at https://e-seimas.lrs.It/portal/legalAct/lt/TAD/TAIS.425608 Accessed 30 Jan 2019 (in Lithuanian).

28. MA/NPA (2018, last update) (Ministry of Agriculture of the Republic of Lithuania/National Paying Agency) Rural Development Programme 20142020. Available at https://www.nma.It/index.php/support/ruraldevelopment-programme-2014-2020/6721 Accessed 10 Feb 2019.

29. Seimas of the Republic of Lithuania (2001) Law on Forests of the Republic of Lithuania. April 10, 2001, No: IX-240. Updated in Jan 01, 2019. Available at https://e-seimas.lrs.It/portal/legalAct/It/TAD/TAIS.6036/ICRhuZYmBR. Accessed 25 Feb 2019.

30. ME/SFS/ASU (2018) (Ministry of Environment of the Republic of Lithuania/ State Forest Service/Aleksandras Stulginskis University) National Forestry Accounting Plan by Lithuania. The document prepared in line with the Regulation (EU) No 2018/841 of the European Parliament and of the Council. Available at https://am.Irv.lt/uploads/am/documents/files/\%C5\% A0ESD\%20apskaitos\%20ir\%20kt\%20ataskaitos/LT\%20National\%20Forestry\%2 OAccounting\%20Plan\%202018_final.pdf. Accessed 30 Jan 2019.

31. ME/SFE (2019) (Ministry of Environment of the Republic of Lithuania/State Forest Enterprise). Strategy of State Forest Enterprise Activity 2019-2023 [V] Valstybinių mišku urédijos 2019-2023 metų veiklos strategija]. Available at https://www.vivmu.lt/wp-content/uploads/2019/02/NI-VMU-strategija-2019-2 023-m.pdf. Accessed 19 Feb 2019 (in Lithuanian).

32. ME (2014) (Ministry of Environment of the Republic of Lithuania) Regulations on Wood Ash Disposal and Use. The document No. D1-14, available from January 5, 2011; updated edition No. D1-572, available from June 25, 2014. Available at https://www.e-tar.lt/portal/lt/legalAct/TAR.AAC6 96779441/elkzLbkTTE. Accessed 30 Jan 2019 (in Lithuanian).

33. Seimas of the Republic of Lithuania (2015) Regulations for forest fellings. January 27, 2010, No. D1-79; updated on September 30, 2015. Available at: https://e-seimas.lrs.lt/portal/legalAct/lt/TAD/TAIS.364764/SrWjOPTLxm. Accessed 14 Feb 2019 (in Lithuanian).

34. CEER (2018) Status Review of Renewable Support Schemes in Europe for 2016 and 2017. Public report of Council of European Energy Regulators (CEER). Ref: C18-SD-63-03. 14 December 2018, Belgium. Available at: https:/www.ceer.eu/ documents/104400/-/-/80ff3127-8328-52c3-4d01-0acbdb2d3bed.

35. Biomass Exchange: trade overview. The energy exchange operator [Energijos išteklių birža] BALTPOOL (2017) Available at https:/www.baltpool.eu/en/activity/. .

36. Šilininkas M (2018) Biokuro rinkos aktualijos privačiu mišku ištekliu racionalesnio naudojimo galimybiu kontekste. Available at http:// miskininkas.eu/wp-content/uploads/2018/09/M_Silininko_prezentacija_201809-07.pdf. (in Lithuanian).

37. Lithuania's National Inventory Report (2018) Greenhouse Gas Emissions 19902016. Available at: http://klimatas.gamta.lt/files/LT_NIR_20180415_final.pdf. .

38. Official Statistics Portal (2016). Statistics Lithuania. Available at https://osp. stat.gov.It. (in Lithuanian).

39. Werner $S$ (2017) International review of district heating and cooling. Energy 137:617-631

40. LDHA (2017) Lithuania District Heating Association. Available at http://sta. digiart.lt/wp-content/uploads/2019/01/2017-WEB_Final.pdf.

41. NCC (2019) (National Commission for Energy Control and Prices) Statistics on district heating sector. Available at https://www.regula.lt/en/Pages/theheat-energy-sector.aspx. Accessed 15 Jan 2019.

42. Energy Balance (2016) Statistics Lithuania. Vilnius 2017:49

43. Kudaba C (1993) About the studies of glacial relief in the nearest future [Apie glacialinio reljefo tyrinèjimus artimiausioje ateityje]. Geografija 29:5-7 (in Lithuanian)
44. IPCC (2006) Guidelines for National Greenhouse Gas Inventories. Agriculture, Forestry and other Land Use, vol. 4. Available at https://www.ipcc-nggip. iges.or.jp/public/2006gl/vol4.html

45. FRA (2015) (Forest Resources Assessment) UN FAO Global Forest Resources Assessment. Available at http://www.fao.org/forest-resources-assessment/ en/. Accessed 30 July 2018.

46. ME/SFS (2017) (Ministry of Environment/State Forest Service). Lithuanian Statistical Yearbook of Forestry 2017 [Lietuvos mišku ūkio statistika 2017]. Butkus A, Dumčiene V, Eigirdas M, Kuliešis A,Vižlenskas D (Eds). Kaunas: Lututè. 184 p. Available at http://www.amvmt.lt/Images/Neikla/STAT/ MiskuStatistika/2017/Metrastis_2017_CD.pdf. .

47. WRB (2014, 2015, last update) World Reference Base for Soil Resources 2014 International soil classification system for naming soils and creating legends for soil maps. World Soil Resources Reports No. 106. FAO. 191 p.

48. Mizaraite D, Mizaras S (2015) Forest land ownership change in Lithuania. COST Action FP1201 FACESMAP Country Report. European Forest Institute CentralEast and South-East European Regional Office. Vienna. 35 p. Available at http:// facesmap.boku.ac.at/library/FP1201_Country\%20Report_LITHUANIA.pdf. .

49. OECD (2018) Corporate Governance in Lithuania, Corporate Governance, OECD Publishing. Paris. Available at. https:/doi.org/10.1787/9789264302617-en

50. Bumblauskis T, Kairiūkštis L, Mikšys V, Raguotis A, Tamošaitis J (1998) Biological resources: the balance of the biomass and mortmass and the regularities of a change in postglacial Lithuania. In: Kairiūkštis L, Rudzikas Z (eds) Ecological Sustainability of Regional Development in a Historical Perspective: Lithuanian Case Studies (ECOSLIT). International Centre for Scientific Culture - World Laboratory Lithuanian Branch, Vilnius, pp 70-79

51. Litbioma (2017) The Lithuanian Biomass Energy Association. Available at http://www.biokuras.lt.

52. Sadauskienè L, Aleinikovas M, Varnagirytė-Kabašinskienė I (2011) Wood for fuel: economy and ecology [Medienos naudojimas kurui: ekonomika ir ekologija]. Mokslas ir gyvenimas 8-9:17-19 (in Lithuanian)

53. Linkevičius E, Röhle H, Schröder J (2019) Generic applicability of nondestructive biomass yield models for willow short rotation coppice: a case study for Germany and Lithuania. Biomass Bioenerg 121:89-98

54. Linkevičius E, Röhle H, Schröder J (2017) Biomass models for short rotation willow plantations in Lithuania. Int Sci Conf Rural Dev:657-662

55. Konstantinavičienė J, Škèma M, Stakènas V, Aleinikovas M, Šilinskas B, Varnagirytè-Kabašinskienè I (2017) Above-ground biomass of willow energy plantations in Lithuania: pilot study. Balt For 23:658-665

56. MA/NPA (2019) (Ministry of Agriculture of the Republic of Lithuania/ National Paying Agency) Statistics of Crop Declaration in Lithuania. Ministry of Agriculture of the Republic of Lithuania, National Paying Agency https:// www.nma.lt/index.php/\%20parama/tiesioginesismokos/\%0Astatistika/349.

57. Mizaras S, Sadauskienè L, Mizaraitė D (2011) Cost and profitability of biofuel chipping in Alnus incana stands in Lithuania. Scand J For Res 26(2):154-160

58. Rytter L, Ingerslev M, Kilpeläinen A, Torssonen P, Lazdina D, Löf M, Madsen P, Muiste P, Stener L-G (2016) Increased forest biomass production in the Nordic and Baltic countries - a review on current and future opportunities. Silva Fennica 50 (5) article id 1660.

59. Mikšys V, Varnagirytė-Kabašinskienè I, Stupak-Møller I, Armolaitis K, Kukkola M, Wójcik J (2007) Above-ground biomass functions for Scots pine in Lithuania. Biomass Bioenerg 31:685-692

60. Armolaitis K, Varnaginytė-Kabašinskienè I, Stupak I, Mikšys V, Kukkola M, Wójcik J (2013) Carbon and nutrients of Scots pine stands on sandy soils in Lithuania in relation to bioenergy sustainability. Biomass Bioenerg 54:250-259

61. Varnagirytè-Kabašinskienè I, Armolaitis K, Stupak I, Kukkola M, Wójcik J, Mikšys V (2014) Some metals in aboveground biomass of Scots pine stands in Lithuania. Biomass Bioenergy 66:434-441

62. Ozolinčius R, Armolaitis K, Mikšys V, Varnagirytè-Kabašinskienè I (2006, (2011) Recommendations for compensating wood ash fertilization. KaunasGirionys: Ministry of Environment of the Republic of Lithuania/Institute of Forestry of Lithuanian Research Centre for Agriculture and Forestry. 17 p. (in Lithuanian with English summary).

63. Pitman RM (2006) Wood ash use in forestry - a review of the environmental impacts. Forestry 79(5):563-588

64. Butkus D, Lebedytè M, Lukšienė B, Šalavèjus S, Druteikienè R, Stelingis K, Tarasiuk N, Špirkauskaitè N, Lujanienė G, Lujanas V, Girgždys A (1998) Radioactive nuclides. In: Kairiūkštis L, Rudzikas Z (eds) Ecological Sustainability of Regional Development in a Historical Perspective: Lithuanian Case Studies (ECOSLIT). International Centre for Scientific Culture - World Laboratory Lithuanian Branch, Vilnius, pp 36-44 
65. Tsybulko NN (2016) Usage optimization of the radionuclide-contaminated agricultural lands and agrochemical protection events in the remote period of the Chernobyl accident. Dissertation, National Belarus Academy Science, Minsk. 48 p. (in Russian).

66. Ozolincius R, Varnagiryte I, Armolaitis K, Karltun E (2005) Initial effects of wood ash fertilization on soil, needle and litterfall chemistry in Scots pine stands. Balt For 11(2):59-67

67. Ozolinčius R, Armolaitis K, Raguotis A, Varnagirytè I, Zenkovaite I (2006) Influence of wood ash recycling on chemical and biological condition of forest Arenosols. J For Sci 52:79-86

68. Ozolinčius R, Buožytè R, Varnagirytė-Kabašinskienè I (2007) Wood ash and nitrogen influence on ground vegetation cover and chemical composition. Biomass Bioenergy 31:710-716

69. Ozolinčius R, Varnagirytè-Kabašinskienè I, Armolaitis K, Gaitnieks T, Buožytè R, Raguotis A, Skuodienè L, Aleinikovienè J, Stakènas V (2007) Initial influence of compensatory wood ash fertilization on soil, ground vegetation and tree foliage in Scots pine stands. Balt For 13(2):158-168

70. Ozolinčius R, Varnagiryté-Kabašinskienè I, Stakẻnas V, Mikšys V (2007) Effects of wood ash and nitrogen fertilization on Scots pine crown biomass. Biomass Bioenergy 31:700-709

71. Haglund N, Expert group (2008) Guideline for classification of ash from solid biofuels and peat utilised for recycling and fertilizing in forestry and agriculture. Published as a part of the Nordic Innovation project "Market harmonisation by dissemination on new solid biofuel standards and development of ash classification and storage guidelines". Available at: https://p29596.typo3server.info/fileadmin/Files/Documents/06_Publications/ GUIDELINE_FOR_CLASSIFICATION_OF_ASH.pdf. .

72. Kim YJ, Wilson C (2019) Analysing future change in the EU's energy innovation system. Energy Strategy Reviews 24:279-299

73. EC (2015) Towards an integrated strategic energy technology (SET). Plan: accelerating the European Energy System Transformation. Brussels, Belgium.

74. EC (2017) Sustainable and optimal use of biomass for energy in the EU beyond 2020. Final report. Available at: https://ec.europa.eu/energy/sites/ ener/files/documents/biosustain_report_final.pdf.

75. Lukoševičius V (2019) Lithuanian District Heating celebrates its 80th anniversary. Available at: https://www.euroheat.org/news/district-energy-inthe-news/ithuanian-district-heating-celebrates-80th-anniversary/. .

76. Vitunskienè V, Aleknevičienè V, Miceikienè A, Čaplikas J, Miškinis V, Pilvere I, Makutènienè D, Dabkienè V, Lekavičius V, Øistad K, Ramanauskè N, Kargyté V, Jazepčikas D, Serva E, Markelyte A (2017) Lithuanian bioeconomy development feasibility study. Available at: https://eimin.Irv.lt/uploads/eimin/ documents/files/Inovaciijos/bioekonomikos\%20studija/Lithuanian\%2 OBioeconomy\%20Study_EN(1).pdf. .

77. Pang X, Trubins R, Lekavicius V, Galinis A, Mozgeris G, Kulbokas G, Mörtberg $U$ (2019) Forest bioenergy feedstock in Lithuania - renewable energy goals and the use of forest resources. Energy Strategy Reviews 24:244-253

78. IINAS/EFI/JR (2014) Forest biomass for energy in the EU: current trends, carbon balance and sustainable potential for BirdLife Europe, EEB, and Transport \& Environment. Final report. Prepared by International Institute for Sustainability Analysis and Strategy, European Forest Institute, Joanneum Research. Available at: http://www.birdlife.org/sites/default/files/ attachments/INAS_EFI_JR_2014_Forest_biomass_energy_EU.pdf. Accessed 19 Aug 2019.

79. EC (2010) Report from the Commission to the Council and the European Parliament on sustainability requirements for the use of solid and gaseous biomass sources in electricity, heating and cooling $\operatorname{SEC}(2010) 65$ final SEC(2010) 66 final; /* COM/2010/0011 final *. Available at: https://eur-lex. europa.eu/legal-content/EN/TXT/?uri=CELEX\%3A52010DC0011.

\section{Publisher's Note}

Springer Nature remains neutral with regard to jurisdictional claims in published maps and institutional affiliations.

Ready to submit your research? Choose BMC and benefit from:

- fast, convenient online submission

- thorough peer review by experienced researchers in your field

- rapid publication on acceptance

- support for research data, including large and complex data types

- gold Open Access which fosters wider collaboration and increased citations

- maximum visibility for your research: over $100 \mathrm{M}$ website views per year

At BMC, research is always in progress.

Learn more biomedcentral.com/submissions 